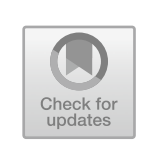

\title{
Foreign Aid and Humanitarian Assistance
}

The US and the EU together provide two-thirds of global humanitarian assistance for the alleviation of emergencies arising from natural and manmade disasters and $80 \%$ of global foreign aid for longer-term development assistance programs. There is no other foreign policy area in which the US and the EU enjoy such a dominant global role.

The entire post-war transatlantic relationship is arguably rooted in humanitarian assistance and foreign aid. The reconstruction of Western Europe was due in large part to the 1948 Marshall plan in which the United States provided over $\$ 12$ billion (nearly $\$ 100$ billion in 2016 US dollars) in economic assistance over a four-year period. The motivations were mixed, of course: partly humanitarian in order to provide relief to people lacking food, shelter, and basic services, but also to promote prosperity, democracy, and stability in Europe and therefore create both a bulwark against Communism and future customers of US exports. The massive reconstruction effort, in which my maternal grandfather was involved, served as an inspiration for a growing system of grants and lowinterest loans provided by the United States and later Europe to poor, newly independent countries in Africa and Asia.

Humanitarian assistance and foreign aid address different challenges. Moreover, the former is delivered according to need and the principles of impartiality and humanity, whereas the latter often reflects strategic political and economic interests of the donors. And yet the two are intimately related. If immediate relief is not coupled with long-term policies to promote structural changes, history will simply repeat itself and require the

(C) The Author(s) 2020

A. L. Gardner, Stars with Stripes, https://doi.org/10.1007/978-3-030-29966-8_12 
US and the EU to undertake repeatedly costly emergency measures to respond to disaster. Indeed, some short-term solutions can be counterproductive: The dumping of food aid in local markets to address urgent food needs, for example, can undermine the ability of poor countries to develop sustainable farms and functioning markets.

During my diplomatic post, I witnessed first-hand how the US and the EU work together in several areas of both humanitarian assistance and foreign aid. There are notable differences in how they pursue their agenda, including their degree of willingness to partner with the private sector and the military, but these have not prevented frequent and deep collaboration.

\section{The Struggle to Contain the Ebola Outbreak in Western Africa}

In the fall of 2014, my wife and I found ourselves in a large, abandoned field in downtown Brussels to visit the training site of Médecins Sans Frontières (MSF), also known as Doctors Without Borders, a non-profit and non-governmental international medical organization of French origin best known for its projects in conflict zones and in countries affected by endemic diseases. We were impressed by the explanations about how the modular kits in the large containers lying in a storeroom could be rapidly shipped to humanitarian disaster zones around the world and assembled on site within hours to provide functioning power generators, water purification, lodging for aid workers, medical treatment, and waste disposal. The logistical know-how and deep experience of MSF made it the first, and sometimes most significant, responder to major medical emergencies.

Although the logistics were interesting, what really grabbed our attention was the sight of several of the organization's instructors training staff on how to put on and take off protective clothing to avoid contamination. The eight-piece clothing, entirely covering the human body, looked like a space suit but was more ominous because it was being worn on land to respond to the outbreak of the Ebola virus in West Africa in March 2014. The scene reminded me of Outbreak, a film released in 1995 starring many Hollywood icons, including Dustin Hoffman, Kevin Spacey and Morgan Freeman. The film was about the public panic and response by military and civilian agencies in the wake of a fictional outbreak of an 
Ebola-like virus in Zaire, and later in a small town in California. A reallife outbreak of the Ebola virus was ongoing in Zaire when the film was released. The film contained exaggerations to enhance its shock value but wasn't too far from fact.

We were transfixed by the demonstration. Our guide told us that medical staff could only wear the space suit for several hours in real-world conditions on the ground because temperatures inside the suits can easily reach up to 46 degrees centigrade (nearly 115 degrees Fahrenheit). The suit takes a long time to put on in order to ensure that the body is entirely protected from contamination. Taking off soiled suits requires even longer (up to twenty minutes) because of a meticulous and rigorous twelve-step process that healthcare workers must repeat three or more times per day. It was clear that there is no margin for error. We were also shown disinfection routines, sample containment wards for infected patients, and the incineration units for soiled clothing and used equipment.

During the first months following the detection of an Ebola outbreak in March, MSF was the most effective response of the developed world. MSF remained on the ground throughout the crisis, even when 28 staff members contracted the virus and 14 died. On top of this risk of infection, MSF workers also faced angry opposition from villagers suspecting that the treatment facilities were spreading the disease. MSF had to close one facility in southern Guinea after being attacked in April 2014 by a stone-throwing mob. Villagers later killed eight African members of an MSF team trying to raise awareness of Ebola in the region. Despite these risks, MSF had nearly 300 international workers and 2900 local employees fighting the outbreak by the time my wife and I were touring the facility in Brussels.

By contrast, the EU and its member states struggled to come up with a coherent and decisive response in the early months of the crisis. This was disappointing in light of the EU's deep partnership with Africa, Europe's proximity to the continent and greater vulnerability to a spread of Ebola, and the history of France and Britain as former colonial powers in Guinea and Sierra Leone. Similarly, the initial US response was slow and focused on domestic preparations. It took until the fall of 2014 for the US and the EU to respond in a coordinated fashion.

Our joint response should have been more effective. As I toured the MSF facility I recalled how, as a young Director for European Affairs in the White House in 1994-1995, I had played a role in the US-EU New Transatlantic Agenda that had specifically flagged the importance of transatlantic cooperation on infectious diseases: 
We are committed to develop and implement an effective global early warning system and response network for new and re-emerging communicable diseases such as AIDS and the Ebola virus, and to increase training and professional exchanges in this area. Together, we call on other nations to join us in more effectively combating such diseases. ${ }^{1}$

We did not make as much progress on this key challenge as we would have liked in the subsequent twenty years.

Our MSF guide explained that an Ebola outbreak starts when a human has direct contact with the blood, body fluids, or organs of infected animals, such as bats, chimpanzees, monkeys, or gorillas. The transmission of the virus from that human to other humans occurs through personal direct contact either with the patient's blood or other body fluids (including sweat and saliva) or through contact with objects, such as needles and syringes, that contain these fluids. Transmission of the virus often occurs through caregivers such as family members or medical personnel in homes or healthcare environments where infection-control practices are weak. Ebola crises, such as the one in Zaire that occurred when Outbreak was playing in movie theaters, can be amplified by the transmission of the virus in overcrowded hospitals and burial practices in which highly infectious corpses are washed or touched by family and members of the community in a sign of love for the deceased.

Ebola is a disease from one of the deeper circles of Dante's Hell. Fortunately, it is not transmitted through the air, like influenza or tuberculosis, or transmitted before symptoms appear, like measles or HIV. Nonetheless, it can result in terrible consequences for its victims and can spread quickly if not brought under control. In its early phase, victims of Ebola can be misdiagnosed because it is relatively rare and because some of the symptoms, including fever, fatigue, muscle pain, and headache, are difficult to distinguish from those of other infectious diseases, such as malaria and typhoid fever. Victims often subsequently experience vomiting, diarrhea, rashes, and hemorrhages resulting in internal and/or external bleeding. The dysfunction or collapse of multiple body organs leads to severe injury and often death. The fatality rate varies from 25 to $90 \%$, depending on the strain.

${ }^{1}$ The document was signed in Madrid at a US-EU Summit on December 3, 1995. http://www.europarl.europa.eu/cmsdata/124321/new_transatlantic_agenda_en.pdf. 
The Ebola outbreak in West Africa in 2014 was first reported by the World Health Organization on March 23 in a remote, forested region of south-eastern Guinea bordering Liberia and Sierra Leone. Multiple chains of transmission of the virus had gone unrecognized for months. By the end of the year, the virus had claimed 6000 lives and had infected 17,000 persons; by March 2015, the numbers were 9200 dead and 22,900 sick; and by the time the crisis had been brought under control in March 2016 , the dead numbered 11,325 . The number of infections and deaths far exceeded those in approximately twenty previous outbreaks since the 1970s in central and eastern Africa; in each of those outbreaks, the number of reported cases never exceeded 500 .

There were many reasons for the severity of the crisis. Like the remote areas of central and eastern Africa where prior outbreaks occurred, the virus appeared in a remote area of Guinea. Normally, this might have helped contain the disease, but in an unfortunate twist of geographic fate the region lay at the junction of Guinea with Sierra Leone and Liberia where people regularly move across borders. The region's lack of rudimentary public health infrastructure, partly because of its recent history of civil war and violence, and its lack of experience with a previous outbreak of the virus compounded the problem.

As the virus spread to urban areas and expanded into an epidemic, the number of cases quickly overwhelmed the capacity of diagnostic and other healthcare facilities. At the onset of the outbreak, there was a very small number of experienced healthcare workers to deal with it, including in Europe and the United States. Even at MSF, involved in most of the prior outbreaks, there were only 40 "veterans." Medical teams were simply not prepared to deal with a disease that kills at least $50 \%$ of its patients and for which no treatments existed. Had Ebola been a First World disease, there would have been a vaccine. But there wasn't because, in the eyes of the major pharmaceutical companies, the numbers of patients are small, and nearly exclusively in the Third World. The business case for the recovery of significant upfront research and production costs had simply not been present.

Some Ebola Treatment Units (ETUs) were filled beyond capacity, requiring the facilities to turn away people suspected of having the disease, thereby fostering new chains of transmission. One of the critical factors in bringing an Ebola outbreak under control-an exhaustive tracing of contacts between victims and others with whom they had been in contact-was absent. Moreover, poor infection control in hospitals led to 
many infections and deaths among healthcare workers and a rapid collapse of the region's healthcare system. The control of other devastating viruses, such as malaria, and even the provision of routine medical services declined. I had seen reports from our embassies that people who collapsed from heart attacks were sometimes left to die because no one wanted to touch them for fear that they had contracted Ebola. Children started missing out on education because of school closures.

Generalized fear and even panic threatened to devastate the region's economies, especially by reducing agricultural output and trade, while driving up prices. My friend and former colleague Samantha Power, US ambassador to the United Nations during President Obama's second term, visited Brussels several times to brief and coordinate with EU officials on the Ebola crisis after her trips to the infected region. On one of those trips, she relayed reports that farming communities were "eating their seeds," indicating not only that current harvests were poor but warning that future harvests and even food security were in danger. A total collapse of civil society was imminent as governments lost control of the situation.

In the early days of the crisis, the EU allocated extra emergency funding to MSF and other humanitarian organizations, such as the Red Cross and Red Crescent, the International Medical Corps, Save the Children and the International Rescue Committee. The aid contributed to the faster deployment of doctors and nurses and the purchase of diagnostic equipment and medical supplies. Disaster Assistance Response Teams of the US Agency for International Development (USAID) and teams from the Atlanta-based Centers for Disease Control and Protection (CDC) were deployed to the region to carry out an assessment of what needed to be done. The US airlifted significant amounts of personal protective gear, generators, and medical equipment. By early summer, it seemed that wiring funds and providing assistance from a distance would be enough as the number of reported cases leveled off and then dropped, suggesting the outbreak could be contained as in the 23 previously reported outbreaks in Africa since 1976.

Instead, the virus spread. By late July it reached, for the first time in history, densely populated metropolitan areas, not only in the three countries of origin but further afield. A traveler with Ebola had flown from Monrovia, Liberia, to Lagos, Nigeria, Africa's most populous city (with 21 million inhabitants) where he had contact with multiple people who later contracted the illness. A massive effort by the Nigerian government, assisted by the CDC, managed to contain the outbreak to just 19 cases 
in two cities. By early August, the World Health Organization categorized the outbreak as a "public health emergency of international concern," a declaration that caught media headlines and unlocked significant new funding. Claus Sorensen, an old friend and the director-general of European Civil Protection and Humanitarian Aid Operations (ECHO), conceded that in an Ebola crisis "speed is of the essence, and there is a feeling that all of us have been behind the curve." 2

The decisive factor in galvanizing action in the EU and the US was a series of shocking announcements regarding the Ebola infections outside Africa. In late July and early August, two US citizens, including a doctor with Samaritan's Purse, were repatriated to Atlanta, where they (successfully) underwent treatment for Ebola in a specialized isolation ward in Emory University Hospital. They were the first two patients ever to receive such treatment in the United States. In early October, two Spanish priests died in Madrid after contracting the virus in Sierra Leone; a nurse who had treated them also tested positive (but later recovered), the first person to have been infected outside of West Africa. Shortly thereafter a Liberian national who had recently returned from Liberia to the United States died of Ebola in a Dallas hospital. The nurses who had cared for him contracted the virus but recovered.

On top of the shock of Ebola infections appearing in Europe and the United States, public health authorities on both sides of the Atlantic conducted modeling about the potential spread of the virus. The results were sobering: In September, the CDC estimated that approximately 555,000 Ebola cases ( 1.4 million cases when corrected for under-reporting) could occur in West Africa by January 20, 2015, if approximately $70 \%$ of all persons with new cases were not effectively isolated. The World Health Organization projected that new Ebola cases could reach 10,000 per week by December. When respondents to a telephone poll were asked in October whether they were concerned that there would be a large outbreak of Ebola in the United States within the next 12 months, 50\% reported that they were "very" or "somewhat" concerned.

The initial US response (before October) was largely domestic because the country was not prepared for an epidemic of this magnitude. When

\footnotetext{
2 Andrew Higgins, "European Leaders Scramble to Upgrade Response to Ebola Crisis," The New York Times, October 8, 2014. https://www.nytimes.com/2014/10/09/world/ european-leaders-scramble-to-upgrade-response-to-ebola-crisis.html.
} 
the crisis broke out, only one facility in the United States (the CDC laboratory in Atlanta) was qualified to test for Ebola and there were only three facilities that could treat Ebola patients; by January 2015 there were 55 laboratories in 43 states that could do so and by October there were 51 treatment centers in 16 states. During that period, 150,000 healthcare workers received instruction on how to identify, isolate, diagnose, and care for patients under investigation for Ebola.

The CDC and Customs and Border Protection implemented intensive screening of air passengers arriving from West Africa. There was significant public support for cutting off all air links with West Africa and quarantining anyone who had recently been in the region. While generalized measures of this kind were avoided, the Defense Department did impose a 21-day quarantine for all personnel returning from Ebola-affected areas, regardless of risk, because of political rather than scientific considerations. The presidential commission established to review the government's response to the Ebola crisis was scathing in its final report. It criticized federal, state, and local unpreparedness to cope with the threat of an epidemic and the government's focus on the political implications of public reactions rather than on the underlying health concerns. ${ }^{3}$

By the end of the year, the US government's response started shifting decisively toward attacking Ebola at its source. President Obama was clear about the stakes:

this is an epidemic that is not just a threat to regional security - it's a potential threat to global security if these countries break down, if their economies break down, if people panic. That has profound effects on all of us, even if we are not directly contracting the disease. ${ }^{4}$

The United States and the EU (as well as its member states), together and in parallel, supported by the African Union and several African countries, finally undertook a major and highly successful effort to bring the crisis

3 "Ethics and Ebola: Public Health Planning and Response," Presidential Commission for the Study of Bioethical Issues, February 2015. https://bioethicsarchive.georgetown. edu/pcsbi/sites/default/files/Ethics-and-Ebola_PCSBI_508.pdf.

${ }^{4}$ Remarks by the President on the Ebola Outbreak, September 16, 2014. https:// obamawhitehouse.archives.gov/the-press-office/2014/09/16/remarks-president-ebolaoutbreak. 
under control. Washington focused on Liberia, while Paris focused on Guinea and London on Sierra Leone.

Speaking at the CDC in mid-September, President Obama announced that the US military had recently dispatched 3000 personnel to Monrovia to establish a base under the control of US Africa Command. Its main objectives were to build 15 ETUs, including new isolation spaces and more than 1000 beds, and to recruit and train more than 1500 medical personnel to staff them. The Department of Defense built seven mobile laboratories in West Africa that cut turn-around times for testing blood samples from five to seven days to between three and five hours, thereby freeing up bed space in overcrowded clinics and hospitals. The UK and France quickly followed the US example with similar military missions of their own to Sierra Leone and Guinea to build hospitals and diagnostic centers; our experts often singled out the UK effort as being rapid and effective in bringing down new infection rates.

In addition to these efforts, thousands of CDC employees and government-supported civilians were deployed in all of West Africa, partnering with national governments to train healthcare workers, treat patients, staff field laboratories, trace contacts of patients to identify chains of transmission, develop border and airport-screening programs, promote safe burials, and educate communities. The United States was to airlift more than 400 metric tons of personal protective equipment and other medical and relief supplies during the subsequent months. In the fall of 2014, the White House announced major efforts to accelerate the development of vaccines (to prevent new infections) and therapeutics (to treat those already infected). And in December the US Congress overwhelmingly supported legislation providing $\$ 5.4$ billion in emergency funding for the CDC and other health services, the State Department, and USAID; much of this funding was earmarked for the prevention, detection, and response to the Ebola crisis in West Africa, as well for efforts to assist in the region's recovery. ${ }^{5}$

The EU made an important contribution as a coordinator and donor. The European Centre for Disease Prevention and Control, headquartered in Sweden, coordinates the work of health experts in different countries but does not have its own emergency-response teams. Similarly, EU member states, rather than the European Commission, dispose of their own

5 "FACT SHEET: Progress in Our Ebola Response at Home and Abroad," The White House Office of the Press Secretary, February 11, 2015. https://obamawhitehouse. archives.gov/the-press-office/2015/02/11/fact-sheet-progress-our-ebola-response-homeand-abroad. 
medical personnel, hospitals, labs, and stock of specialized equipment. But as the only European body with a global picture of the fast-moving epidemic, the European Commission successfully played the role of "traffic cop" to ensure that Europe's response was consistent and effective. That role included the identification of the type and destination of emergency supplies for West Africa, providing a clearinghouse of information about the crisis and the disease, and the creation of a list of available member state assets relevant for the treatment of Ebola in Europe.

The European Commission also played a key role in identifying European assets and trained personnel that could be deployed for the medical evacuation of patients back to Europe and in negotiating a US-EU agreement about when US and European patients could call on their respective emergency medivac "air bridges." Ensuring that international healthcare workers could be airlifted to equipped facilities in Europe within 48 hours was critical to the ability of the US and EU to recruit such workers.

In October, the EU appointed Christos Stylianides, Commissioner for Humanitarian Aid and Crisis Management, as EU Ebola Coordinator to ensure that the EU institutions and member states acted in a coordinated manner with each other and with international partners. In addition to the directorate-general for humanitarian aid, other Commission departments were involved in the response to the Ebola crisis: These were principally the Directorate-General for International Cooperation and Development (DEVCO), the counterpart to USAID and responsible for foreign aid, and the European External Action Service (the EU's diplomatic service with delegations in most countries around the world). The role of other departments also had to be coordinated: The directorate-general for health identified facilities in member states that were willing and able to accept Ebola patients; the directorate-general for internal affairs (including justice and law enforcement) coordinated entry and exit procedures at airports in case of travelers suspected of having Ebola; and the directorategeneral for research worked to promote vaccines and therapies.

The EU was also an important donor to help combat Ebola in West Africa. The European Commission and EU member states contributed almost $€ 2$ billion (without counting the value of in-kind contributions from many member states such as personal protective equipment, vehicles, and field hospitals). Of this total, the European Commission contributed $€ 870$ million out of the EU budget for emergency measures, financial support for the African Union's own medical mission to the region, and 
long-term relief (such as budgetary support for the restoration of vital public services and the strengthening of food security). Moreover, the European Commission announced substantial funding from the EU budget to promote projects on Ebola research, including immediate largescale clinical trials of potential vaccines and tests of existing and novel compounds to treat Ebola. The European Commission also partnered with the European pharmaceutical industry in launching a $€ 280$ million longer-term research program involving clinical trials of new Ebola vaccines, the development of fast diagnostic tests, and new approaches to manufacture, store and transport vaccines.

In summary, while the US and EU were both slow in responding to the Ebola crisis, by the fall of 2014 they had significantly scaled up their efforts and were working very closely together to provide an effective series of measures that brought the crisis under control by the summer of 2015. The lessons learned from that dramatic experience-including European Commission coordination of EU member state activities and intensive US-EU coordination to combat epidemics-are important for coping with future humanitarian disasters. The lessons enabled the US and EU to respond to an outbreak of Ebola in the Democratic Republic of Congo (DRC) in May 2018, the second worst in history and the longest and deadliest of the nation's nine previous outbreaks. USEU cooperation will be equally important in dealing with the outbreak of coronavirus.

\section{Working Together ON OTHER Humanitarian Challenges}

While Ebola and other epidemics are just one area where the US and EU have worked well in humanitarian assistance, they are emblematic of the many other examples of how they are indispensable partners in alleviating suffering around the globe. One example is their delivery of aid to those suffering from the Syrian civil war that has displaced over 6 million people and killed 400,000. The war has been catastrophic, but it would have been far worse without US and EU efforts.

Under the EU's 2014-2020 multi-annual financial plan, the European Commission's annual humanitarian assistance budget averaged $€ 1$ billion per year and is projected to rise under the 2021-2027 budget cycle. In addition to the formal budget, the EU has drawn from other sources to spend hundreds of millions of euros annually to respond to unforeseen 
events and major crises, including the humanitarian disaster caused by the Syrian civil war and the refugee crisis in 2015-2016. Several EU member states-especially the UK, Germany, and Sweden-are generous donors of humanitarian assistance as well. Together with the EU, they provide roughly the same amount of funding as the United States ( $\$ 7$ billion per year as of 2018). US funding, largely administered through a specific bureau within USAID (the Office of US Foreign Disaster Assistance), has responded to the same emergencies as the EU-not only the Ebola outbreak, but also the Syrian civil war and many other crises concentrated in the Middle East and Africa. Both the US and the EU contribute significant amounts through United Nations agencies such as the UN High Commission for Refugees, UNICEF, and other non-governmental organizations such as the World Food Program and the International Red Cross.

The predominance of the US and the EU as humanitarian assistance actors means that their practices shape those of other donors, including states, NGOs, and multilateral organizations. When we join forces to minimize overlaps or inconsistent approaches, we ensure that our dollars and euros have maximum impact, leading to real improvements in the lives of millions of people affected by humanitarian assistance. As one study rightly pointed out:

Failure by these two parties to enhance their cooperation...would result in additional, yet avoidable, human death and suffering..... and could lead to increased insecurity and instability across the globe., threatening US and EU strategic interests. ${ }^{6}$

US administrations of both political parties have recognized the importance of this partnership and for good reason. The George H. W. Bush administration launched an annual strategic dialogue on humanitarian assistance with the EU at senior levels in USAID, the State Department and $\mathrm{ECHO}$, supplemented with regular contacts on the ground among field officers. In the New Transatlantic Agenda concluded in 1995 under the Clinton administration, the US and the EU set forth an extensive list

\footnotetext{
${ }^{6}$ Julia Steets and Daniel Hamilton, eds. "Humanitarian Cooperation: Improving US-EU Cooperation," Report by the Global Public Policy Institute and the Center for Transatlantic Relations, 2009. https://www.urd.org/IMG/pdf/Humanitarian_Assistance_GPPI_ complet.pdf.
} 
of areas where they should work closely, including improving the effectiveness of international humanitarian relief agencies, and urged the creation of joint missions whenever possible, greater operational coordination, staff exchanges, and information sharing. Close dialogue has continued since then, despite the turbulence of US-EU relations during the presidency of Donald Trump.

\section{WORKINg TOGETHER ON Foreign Aid AND DEVElopment}

The US and the EU provide an even larger share of total foreign aid than they provide of total humanitarian assistance. The United States is the largest single provider of foreign aid, accounting for one-quarter of the $\$ 150$ billion disbursed worldwide every year. But the EU, together with its member states (especially Germany, the United Kingdom, and France), provides over half the total foreign aid disbursed. While the US contribution appears generous, it represents only slightly more than $1 \%$ of the US federal budget and about $0.18 \%$ of US GDP, far below the equivalent percentages of many EU member states. ${ }^{7}$

The US-EU partnership on foreign aid has worked well, in part because the two are the biggest players globally. An even bigger reason for the successful partnership is that they share values and objectives such as the promotion of human rights, democracy, good governance, gender equality, and open markets. Nonetheless, their policies occasionally reflect different outlooks and priorities.

US foreign aid policy is often shaped by national security concerns, especially during major wars, and devotes significant resources to military and non-military security assistance (concentrated in Afghanistan, Israel, Egypt, and Iraq). Moreover, US foreign aid is sometimes used as a tool to open global markets to US exports and is often tied to the purchase of US

\footnotetext{
${ }^{7}$ The United Nations has urged countries to spend at least $0.7 \%$ of their GDP on foreign aid, a target met by Sweden, Luxembourg, Norway, Denmark, the Netherlands, and the United Kingdom. According to an opinion poll conducted in the United States in 2014 , Americans on average think that $26 \%$ of the federal budget is spent on foreign aid; given this misconception, many believe that the US should reduce its spending (unlike their European counterparts who support giving generously). See Bianca DiJulio, Jamie Firth, and Mollyann Brodie, "Data Note: Americans' Views On The U.S. Role In Global Health," Kaiser Family Foundation, January 23, 2015. https://www.kff.org/globalhealth-policy/poll-finding/data-note-americans-views-on-the-u-s-role-in-global-health/.
} 
goods and services (especially food). Some US aid is explicitly made conditional on the recipients' agreement to take certain actions. For example, the Millennium Challenge Corporation, a foreign aid agency established by but independent from the US government, provides large five-year grants to countries that meet certain political and economic criteria and sign up to "compacts" detailing the domestic policies they will pursue.

By contrast, the EU's commitment to development assistance is grounded in a widely shared feeling among the European public that the eradication of extreme poverty is a moral obligation and an investment in Europe's long-term security. Unlike the United States, that has the luxury of large oceans on either side, Europe is far more exposed to instability on its borders. Without development assistance, significant migration flows into Europe from Northern Africa and the eastern Mediterranean are certain. While the EU's development assistance is not shaped by military considerations or the desire to promote exports, the EU has recently moved closer to the US view that aid should be subject to strict conditions about the behavior of recipients, especially their willingness to undertake economic reforms.

Most US presidents have considered foreign aid as an investment in global and US security and prosperity, and a significant pillar of US foreign policy, rather than a gift to undeserving foreign countries. President Trump has departed from that consensus by considering foreign aid wasteful and ineffective unless given to allies. In his 2018 speech before the UN General Assembly, President Trump made the latter point in stark terms: "Moving forward, we are only going to give foreign aid to those who respect us and, frankly, are our friends." 8 His White House now appears to see Africa largely as a playground of big-power rivalry, where Chinese and Russian influence is on the rise. Other than as a destination for growing US exports and investment, Africa appears to be of little inherent interest.

The president's budgets have regularly proposed massive cuts in foreign aid. His 2020 budget has called for $20 \%$ cuts in the foreign aid budget - a target that is not only immoral but geo-politically nonsensical in light of the growing influence of China and Russia in Africa and other parts of the developing world. Fortunately, Congress has maintained most of the programs, partly in sympathy with the argument that deploying diplomats and development experts today is cheaper than deploying

${ }^{8}$ Remarks by President Trump to the 73rd Session of the United Nations General Assembly, September 25, 2018. https://www.whitehouse.gov/briefings-statements/ remarks-president-trump-73rd-session-united-nations-general-assembly-new-york-ny/. 
troops tomorrow. In an open letter to Congress in 2017, more than 120 retired admirals and generals argued cogently:

We know from our service in uniform that many of the crises our nation faces do not have military solutions alone...[the] State Department, USAID ... and other development agencies are critical to preventing conflict and reducing the need to put our men and women in uniform in harm's way...The military will lead the fight against terrorism on the battlefield, but it needs strong civilian partners in the battle against the drivers of extremism - lack of opportunity, insecurity, injustice and hopelessness. ${ }^{9}$

As with humanitarian assistance, the 1995 New Transatlantic Agenda also tried to introduce greater structure around US-EU cooperation on foreign aid, especially in their joint efforts to "help developing countries by all appropriate means in their efforts towards political and economic reforms." But efforts at a structured dialogue suffered from disagreements in other areas and were only revived when the US and EU launched a Development Dialogue in 2009. ${ }^{10}$ Although the annual meetings at ministerial level have not always occurred as envisioned by the Dialogue, regular meetings at senior levels and continuous technical exchanges between staff, at headquarters and especially in the field, have enabled the parties to exchange information on policies and programs, as well as to promote greater policy consensus and coordination.

The US-EU annual summit in 2014 that I attended several weeks after I arrived in Brussels issued an ambitious set of targets for the parties' development agenda. ${ }^{11}$ Some of the objectives were aspirational, such as delivering on the "unfinished business" of the Millennium Development Goals, a set of eight extremely ambitious international development goals for 2015 (including the eradication of extreme poverty and hunger) that had been established by the United Nations in 2000. These goals have been replaced by the UN's 17 Global Goals for Sustainable Development, an agenda of social and economic development objectives for 2030 that the US and the EU support.

\footnotetext{
${ }^{9}$ The full text of the open letter can be found here: http://www.usglc.org/downloads/ 2017/02/FY18_International_Affairs_Budget_House_Senate.pdf.

${ }^{10} 2009$ US-EU Summit Declation, November 3, 2009. http://www.europarl.europa. eu/cmsdata/122880/Joint\%20Statement\%202009\%20EU-US\%20Summit.pdf.

${ }^{11}$ EU-US Joint Statement, March 26, 2014. https://www.consilium.europa.eu/media/ 23902/141920.pdf.
} 
US-EU cooperation on foreign aid is not always easy because each party has different budgetary cycles, implementation systems, and measures to ensure accountability. Much of the "real" day-to-day work occurs in the field in dozens of countries, making coordination from headquarters in Washington and Brussels rather complex. Even when coordination is successful, moreover, it can be overtaken by fast-moving events. Representatives of USAID often observed to me that they preferred to deal with EU member states - such as the UK, the Netherlands, Sweden, and Denmark-because they were less bureaucratic and nimbler than the EU.

Nonetheless, the constant dialogue between the US and the EU has enhanced their mutual trust and the effectiveness of their foreign aid programs. One example is how each party has increasingly relied on the other's geographic expertise: USAID relies on France and the EU in francophone Africa where the US has a relatively more modest presence; the EU relies on the United States in the Horn of Africa where the former lacks the latter's resources and expertise. During my diplomatic mission, USAID and DEVCO evidenced their mutual trust and intent to specialize by signing an agreement enabling each to fund the other's projects.

An important by-product of the US-EU dialogue on development is that it has forced each side to coordinate better among its own government departments. In the case of the EU, that means DEVCO, the European External Action Service and also the Directorate-General for Neighbourhood and Enlargement Negotiations (that implements assistance programs in the Western Balkans, Turkey, the former Soviet Union, and the Maghreb). In the case of the United States, that means not only USAID, but also includes the State Department and even the Defense Department, the Department of Health and Human Services, the US Treasury, and the Department of Agriculture. This internal coordination can sometimes be more challenging than transatlantic coordination, as I witnessed many times.

The US and the EU development dialogue has covered a wide range of topics. One of the areas of focus has been the challenge of how to improve the "resilience" of developing countries. In the development context "resilience" means the ability of people, households, communities, countries, and systems to mitigate, adapt to and recover from shocks and stresses in a manner that reduces chronic vulnerability and facilitates economic growth that is fairly distributed across society. Resilience can be strengthened in many ways: for example, with cash transfer programs to provide a safety net to the poorest households in drought-prone areas; by vaccinating livestock and planting crops that are more resistant to pests and 
drought; through early warning systems and insurance against extreme weather, plagues, and earthquakes; and with budget support for countries to maintain vital state functions, including policing and health care services. $^{12}$

The dialogue has also covered topics such as the effectiveness of aid in achieving economic or human development, adaptation to climate change (especially developing countries' implementation of low-carbon growth strategies and adaptation to harsher weather), improving the availability and accessibility of food ("food security"), the interplay between security and development, electrification (with a focus on rural areas in subSaharan Africa), and health. The last four areas merit further elaboration.

At the 2009 G-8 summit in L'Aquila, Italy, members of the G-8 and other donors, including the EU, pledged $\$ 22$ billion to support food security over a three-year period. That initiative led to the launch at the G-8 summit at Camp David in May 2012 of a New Alliance for Food Security and Nutrition between the donors and ten African countries suffering chronic food shortages. The purpose of the initiative is to attract private investment in agriculture, to complement public investment and create the right conditions for the recipient countries to increase agricultural productivity, adopt improved production technologies (including improved seed varieties), and improve their post-harvest management practices to reduce their dependency on food imports and food aid. Under the "cooperation frameworks" signed with the donor countries, the recipients agree to implement reforms in a wide variety of areas, including infrastructure improvements, regulatory and tax reforms, and easier conditions for the marketing and trade in farm products. ${ }^{13}$ Another important example of US-EU cooperation to promote food security in the developing world was the agreement by the Bill and Melinda Gates Foundation and the European Commission to provide $\$ 300$ million each to fund agricultural and climate-change research during 2018-2020 to assist farmers with crop improvement, protection, and management.

\footnotetext{
12 The signature of a cooperation agreement between the US and the EU in 2015 on the sharing of data received from the EU's Copernicus constellation of earth observation satellites will assist joint efforts to manage and mitigate natural disasters. https://landsat.gsfc.nasa.gov/united-states-and-european-unionsign-cooperation-arrangement-on-copernicus-earth-observation-data/.

${ }^{13}$ European Parliament, "The New Alliance for Food Security and Nutrition in Africa," November 2015. http://www.europarl.europa.eu/RegData/etudes/STUD/ 2015/535010/EXPO_STU(2015)535010_EN.pdf.
} 
The US and the EU have both focused on the importance of providing security as a precondition for effective long-term development. Their common views have translated into practical consequences on the ground. For example, the EU and the US ambassadors to South Sudan, working with the United Nations, averted a military confrontation between two tribes a few years after the country achieved its independence in 2011. The Lou Nuer and Murle tribes had been fighting each other for decades over cattle, with revenge killings occurring frequently. The ambassadors traveled together by helicopter to remote and dangerous areas to negotiate with the tribe's leadership and local elders to mediate an end to the impending conflict. As major providers of aid, the EU and especially the US were successful because they insisted that peace was a precondition for continued aid.

Electrification is another focus of US-EU cooperation on development. Two-thirds of the population of sub-Saharan Africa, around 590 million people, lacks access to power. That number is growing as rapid population growth creates demand that outstrips increased supply from investments in electrification. The remaining one-third cannot consume as much power as it would like because of blackouts and brownouts. In rural areas, the average electrification rate is only $16 \%$. The main reasons for this situation include droughts that affect hydropower capacity, aging infrastructure and poor maintenance, unreliable fuel supply and inadequate transmission and distribution capacity. ${ }^{14}$

Lack of electricity has numerous dramatic effects: For example, it stunts industrial growth and agricultural yields, hurts healthcare services (such as hospital care and the delivery of drugs requiring refrigeration), impedes digital connectivity that is increasingly essential to participate in the knowledge economy, and increases the number of premature deaths, especially among women and children, because of household air pollution caused by the use of solid biomass for cooking and of candles and kerosene lamps for indoor lighting. Electrifying Africa, especially subSaharan Africa, is therefore crucial to progress; at the same time, electrification using cleaner fuel sources, such as natural gas and renewable energies, will be key to avoid major harm to the environment from

\footnotetext{
${ }^{14}$ Simone Tagliapietra, "Electrifying Africa: How to Make Europe's Contribution Count," Bruegel, June 2017. http://bruegel.org/wp-content/uploads/2017/06/PC-172017_1.pdf.
} 
meeting the energy needs of a rapidly growing population with dirty coal or oil.

Ensuring that all people in sub-Saharan Africa have access to electricity by 2030 , one of the UN's Sustainable Development Goals, will require a major effort by the region's governments and the international community, above all the United States and the European Union. According to various estimates, the region will need to increase its electrical capacity by about 400 gigawatts and invest at least $\$ 40$ billion per year to achieve this goal. ${ }^{15}$ Attracting that investment from the private sector is a huge challenge because almost none of sub-Saharan electric utilities are currently financially sustainable due to artificially low tariffs, low operational efficiency due to losses during transmission and distribution, and poor bill collection. Wasteful subsidies incentivize inefficient forms of energy, disincentivize maintenance and investment, and overwhelmingly benefit higher income groups. Political patronage, corruption, and a poor regulatory environment present further challenges.

Investments in the electricity sector are overwhelmingly in the traditional fossil fuel sector generating power on the grid rather than in the renewables sector generating power off the grid. The latter, especially in the form of solar photovoltaic, small hydropower and small wind turbines, are especially relevant for the three-fifths of the population that lives in rural areas. Even despite ongoing technological improvements that increase efficiency, renewable energy projects require significant upfront capital commitments and high transaction costs relative to the amount of power produced and the return on investment. Sub-Saharan Africa will only be able to substantially increase electrification rates, especially with renewable energy projects in rural areas, through energy sector reform and international public-private partnerships that mobilize private capital.

There are dozens of international initiatives originating in Asia, the Middle East, Europe, and the Americas to improve access to power in Africa. China is increasingly active, including in sub-Saharan Africa where Chinese contractors (the vast majority of them state-owned) were responsible for $30 \%$ of new electrical capacity between 2010 and 2015. The US

152017 Estimates from Enerdata and the International Energy Agency, cited in Simone Tagliapietra, "Electrifying Africa: How to Make Europe's Contribution Count," Bruegel, June 2017. http://bruegel.org/wp-content/uploads/2017/06/PC-17-2017_1.pdf. 
and the EU are working closely to align their initiatives to promote electrification in sub-Saharan Africa. In 2014, they signed a memorandum of understanding that outlined their cooperation to reduce energy poverty and increase energy access in sub-Saharan Africa. ${ }^{16}$ Although the MOU is non-binding and does not require either party to make financial commitments, it establishes a structure for cooperation in several areas, including joint financial support, stimulating private sector investment, and the alignment of technical assistance and reform efforts.

As of 2017, there were 26 separate initiatives originating from the member states and the EU institutions. While it is understandable that various member states wish to have separate initiatives to promote national political and commercial interests, it appears rather inefficient for the EU institutions (the European Commission and the European Investment Bank) to have numerous ones as well. Nonetheless, during the five years ending in 2020 , the EU budget alone allocated more than $€ 2.5$ billion in grants to support sustainable energy in sub-Saharan Africa; those grants enabled the private sector to commit several times that amount in equity and debt capital as well. Together with the member states, the EU has supported projects that have brought electricity to more than 100 million people in the region.

One of the key projects is the European Commission's Electrification Financing Initiative (ElectriFI) to support the adoption of renewable energy, with an emphasis on decentralized energy solutions in rural areas around the developing world, principally in sub-Saharan Africa. USAID not only assisted the European Commission to structure the program but also approved a US investment of $€ 10$ million in ElectriFi. That investment represented a crucial "seal of approval" that enabled the European Commission to access a far larger pool of capital than would otherwise have been possible. ElectriFI provides financing and technical support, even at an early stage and in partnership with other funders, to enable projects to overcome gaps in available market financing and achieve maturity in order to attract private long-term capital.

The United States has also been active in promoting the electrification of sub-Saharan Africa. Power Africa, announced by President Obama in 2013 , is the largest public-private partnership in history, involving many agencies of the US government, African governments, more than 100

\footnotetext{
${ }^{16}$ Memorandum of Understanding between the United States and the European Union for Reducing Energy Poverty and Increasing Energy Access in Sub-Saharan Africa, signed July 14, 2015. https://www.usaid.gov/sites/default/files/documents/1860/EU\% 20Signed\%20MOU\%20from\%20July\%2014\%202015.pdf.
} 
private sector partners and international organizations like the African Development Bank and the World Bank. Power Africa was underpinned by the US Electrify Africa Act of 2015, passed with overwhelming bipartisan support to promote African developments, as well as to assist US exports and counter Chinese influence. Power Africa was one of the few Obama-era executive decisions that President Trump did not cancel upon entering office; indeed, his administration supported it as a model for how governments can leverage private capital to build infrastructure.

The aim of the initiative has been to finance by 202030 gigawatts of electricity capacity and 60 million new domestic electricity connections, especially from renewable projects in rural areas, by unlocking subSaharan Africa's substantial wind, solar, hydropower, natural gas, and geothermal resources. By the end of 2018, Power Africa had attracted over $\$ 54$ billion in commitments and had catalyzed about $\$ 18$ billion in investment into 120 power projects and over 10 gigawatts of capacity. These projects connected about 12 million homes and 53 million people. Most of these connections are from solar lanterns that power a single light and enable the charging of a mobile phone. As basic as that may sound, even such connections can result in dramatic improvements in livelihood. Power Africa is moving beyond these connections to include larger, more on-grid power projects using non-renewable sources.

In addition to the power sector, both the US and the EU are actively engaged in the promotion of global health. For example, they are the main contributors to the Global Fund to Fight HIV/AIDS, Tuberculosis and Malaria and to the Global Alliance for Vaccines and Immunisation (GAVI). They sit on the governing boards and closely align their policies.

Founded in 2002 as a partnership among governments, nongovernmental organizations, and the private sector, the Global Fund raises and invests the world's money-about $\$ 4$ billion per year-to support programs in more than 100 countries that combat the three deadliest infectious diseases. The EU (the European Commission and EU member states combined) and the United States provide roughly 46 and 36\% 
of the Global Fund's financing, respectively. ${ }^{17}$ The health programs supported with this money have reduced the number of deaths caused by HIV/AIDS, TB, and malaria by one-third since 2002 and have saved 27 million lives, the majority of these in sub-Saharan Africa, as of the end of 2017.

The Global Fund has enabled millions to be on antiretroviral therapy and therefore to be spared the death sentence that HIV/AIDS used to represent. Of the 37 million people living with HIV, 22 million are on antiretroviral therapy (17.5 million of these thanks to the Global Fund). Improved access to HIV treatment has cut the number of AIDS-related deaths in half since the peak in 2005, from 1.8 million to under 1 million in 2017 . However, HIV infections remain very high and especially among adolescent girls and young women who are up to eight times more likely to be HIV positive than young men in some African countries. On the current trajectory, the Global Fund is unlikely to meet its goal of reducing new infections to 500,000 globally by 2020 . In addition to the terrible human cost of the disease, the economic impact of HIV/AIDS is estimated to be over $\$ 7$ billion in lost earnings in 2020 .

The Global Fund provides more than $65 \%$ of all international financing to combat TB. The Global Fund has disbursed about $\$ 6$ billion in the fight against TB by the end of 2017. Much of this has focused on expanding molecular diagnostic technology which delivers faster and more accurate results, supporting programs that identify those living with the disease without treatment, and enabling millions to be treated. Progress is being made: The mortality rate for TB fell by $42 \%$ between 2000 and 2017. But TB remains a serious threat to global health security because it is highly contagious, airborne and increasingly drug resistant. It remains the leading cause of death from infectious disease, with 1.3 million deaths per year, not including HIV co-infections. Deaths from drug-resistant $\mathrm{TB}$ are responsible for about one-third of all deaths due to

${ }^{17}$ The United States also commits billions of dollars to combat HIV/AIDS through the President's Emergency Plan for AIDS Relief, launched by the Bush administration in 2004. Moreover, the Bill and Melinda Gates Foundation has also given $€ 62.5$ million in grants and guarantees to co-finance a European Commission program that mobilizes private investment in laboratory facilities that provide diagnostic services for HIV/AIDs, $\mathrm{TB}$ and malaria. 
antimicrobial resistance worldwide; if trends continue, 2.6 million people will die of drug-resistant TB by 2050 , costing the global economy trillions of dollars in lost output.

The Global Fund is also the leading provider of funding to combat malaria, a disease transmitted to humans by mosquitoes. Malaria is a major killer: In 2017, there were 220 million infections and 435,000 deaths from malaria (most of them children under age 5). In Africa alone the economic impact of malaria is estimated to be $\$ 12$ billion per year, including the costs of healthcare, absenteeism, days lost in education, decreased productivity, and loss of investment. But thanks to the support of the Global Fund, hundreds of millions of insecticide-treated mosquito nets have been distributed and over 100 million cases of malaria have been treated by 2017 . As a result, global malaria deaths have dropped by $60 \%$ since 2000. Unfortunately, progress has stalled in the past few years due to drug and insecticide resistance. Some countries are even losing ground to the disease.

Launched in 2000 with the help of a $\$ 750$ million five-year pledge from the Bill and Melinda Gates Foundation, GAVI is an international organization that brings together the public and private sectors in the shared goal of creating access to new and underused vaccines for children living in the world's poorest countries. The US and the EU are among GAVI's six original donor countries; as with the Global Fund, they are the largest donors, providing roughly $\$ 270$ million each per year. GAVI estimates that it has helped treat over 690 million children and has prevented more than 10 million future deaths in the first 17 years of its existence.

\section{Looking to The Future}

Demands on foreign aid and humanitarian assistance are certain to grow in the future, principally because of population growth and climate change, causing extreme weather patterns (including heat and drought), pests, disease, and rising oceans. Some studies predict that of the 2.4 billion increase in world population between 2015 and 20501.3 billion will be in Africa. The OECD estimates that by 2030 half a billion people may be living in "fragile states," defined as countries that are incapable of exercising basic functions, because of climate change and conflict.

Every year hundreds of millions of people require humanitarian assistance, largely because of natural disasters and conflicts. Hunger is one of 
the main urgent challenges: The Food and Agriculture Organization estimates that over 800 million people suffer from food insecurity, of which over 100 million (roughly half of them children) face acute hunger, even starvation. Only one-fifth of children affected by severely acute malnutrition receive adequate care, with the result that many become ill and suffer impaired growth and cognitive development.

There are nearly 70 million people around the globe-principally in Syria, Turkey, Lebanon, Palestine, Yemen, Afghanistan, South Sudan, Somalia, and Myanmar-requiring protection, shelter, food, and other basic services due to forced displacement, often lasting a decade or more. Very often these people lack access to water, sanitation, and hygiene, resulting in heightened risk of epidemic outbreaks.

The World Bank estimates that $38 \%$ of land area worldwide, home to approximately $70 \%$ of the world's population, is exposed to drought. At the same time, rapid population growth and urbanization are contributing to a steady increase in the demand for water. As a result, the number of people without access to safe drinking water is expected to double by 2025 to 2 billion.

In light of increasing demand for urgent humanitarian assistance and longer-term development aid, the US and the EU, including its member states, need to build on their cooperation as the world's leading donors to coordinate more frequently and deeply than ever before. This coordination is not only necessary to make the dollars and euros stretch further, but also to ensure that their common values shape the global development agenda despite the rapid rise of new state donors (especially China) that are focused almost exclusively on the expansion of political power and economic ties, rather than the promotion of democracy, human rights, and good governance. ${ }^{18}$

The US and the EU also need to work together to ensure that their activities in foreign aid and humanitarian assistance are consistent with the growing role of private development assistance coming from NGOs, foundations, and corporations in the OECD. It will be more challenging, but important, for the US and EU to reconsider some of their policies that undermine their joint objectives to promote more stable economic and political conditions in the poorest countries. In the case of the US,

${ }^{18}$ European Parliamentary Research Service, "Addressing Global Poverty and Insecurity Through Better Transatlantic Cooperation," September 2016. http://www.europarl. europa.eu/RegData/etudes/BRIE/2016/586646/EPRS_BRI(2016)586646_EN.pdf. 
that means its practice of tying aid to the purchase of US agricultural commodities. In the case of the EU, that means its practice of dumping into African markets the cheap surplus food that results from generous European production subsidies; and it also means its opposition to genetically modified food and feed that prevents African countries from accepting some food aid and planting more resilient crops. ${ }^{19}$

Acknowledgements The invaluable assistance of Dr. Emmanuel De Groof in the preparation of this chapter is gratefully acknowledged.

19 "Better Dead Than GM-Fed," The Economist, September 19, 2002. Emmet Livingstone, "How EU Milk Is Sinking Africa's Farmers," Politico, April 8, 2018. 